IUCN Academy of Environmental Law $15^{\text {th }}$ Colloquium University of Cebu Philippines 29

May-2 June 2017

\title{
Caring for our Oceans and their Biodiversity
}

Trevor Daya-Winterbottom, Faculty of Law, University of Waikato

\section{A. INTRODUCTION}

This paper will explore and critically analyse national strategies for oceans governance and protecting marine biodiversity from a transnational perspective. For example, during 2016 New Zealand launched a public consultation exercise regarding a new Marine Protected Areas Act, ${ }^{1}$ and published statistical reports on the marine environment ${ }^{2}$ and the marine economy ${ }^{3}$ and a biodiversity action plan. ${ }^{4}$ More recently, the previous New Zealand government advised that a major plank of its legislative program during 2017 would be the enactment of the new Marine Protected Areas Act.

Looking at these New Zealand policy developments from a transnational perspective will firmly ground this paper in terms of considering how international environmental law obligations are implemented through both vertical comparison with the international legal order, and horizontal comparison between jurisdictions.

\section{B. MARINE PROTECTED AREAS IN NEW ZEALAND}

This section analyses New Zealand policy developments regarding place based approaches to protecting marine biodiversity, and the tension between narrow conceptions of marine protected areas (MPAs)

1 Ministry for the Environment, A New Marine Protected Areas Act (Ministry for the Environment, Wellington, 2016).

2 Ministry for the Environment and Statistics New Zealand, Our marine environment 2016 (Ministry for the Environment and Statistics New Zealand, Wellington, 2016).

3 Statistics New Zealand, New Zealand's marine economy: 2007-13 (Statistics New Zealand, Wellington, 2016).

4 Department of Conservation, New Zealand Biodiversity Action Plan (Department of Conservation, Wellington, 2016). 
IUCN Academy of Environmental Law $15^{\text {th }}$ Colloquium University of Cebu Philippines 29 May-2 June 2017

focused on sovereignty within the territorial seas and wider conceptions of MPAs traversing other marine zones focused on international law derived jurisdiction.

The Marine Reserves Act 1971 (MRA) was a ground-breaking statute and provides for marine reserves to be declared by the GovernorGeneral by Order in Council within the $12 \mathrm{~nm}$ territorial sea, after the application, consultation, notification and objection process in $\mathrm{s} 5$ has been complied with. ${ }^{5}$ Marine reserve applications can be made by any university; any body appointed to administer land fronting the coast subject to the Reserves Act 1977; any corporate entity or other organisation engaged in scientific study of marine life or natural history; any Maori with tangata whenua status over the area; or the Director-General of Conservation. ${ }^{6}$ The purpose of declaring marine reserves is to preserve: ${ }^{7}$

... for the scientific study of marine life, areas of New Zealand that contain underwater scenery, natural features, or marine life, of such distinctive quality, or so typical, or beautiful, or unique, that their continued preservation is in the national interest.

Marine reserves are required to be preserved in their natural state, marine life is required to be protected and preserved, the value of the reserve as the natural habitat for marine life is required to be maintained, and, subject to meeting these objectives, full and free public access is required to be provided. ${ }^{8}$ More significantly, fishing is prohibited within marine reserves except as authorised by the notice declaring the reserve, or as authorised by the Director-General for scientific purposes. ${ }^{9}$ To date, 44 marine reserves have been declared since 1971, covering approximately 7 per cent of the New Zealand territorial sea. ${ }^{10}$ However, the majority of the area covered by marine

\footnotetext{
5 MRA, S 4.

6 MRA, S 5(1).

7 MRA, S 3(1).

8 MRA, S 3(2).

9 MRA, ss 3(3) and 11(b).

10 Department of Conservation, "Marine Protected Areas" <www.doc.govt.nz>; Ministry for the Environment, Environment New Zealand 2007 (Ministry for the Environment, Wellington, 2007) 334.
} 
IUCN Academy of Environmental Law $15^{\text {th }}$ Colloquium University of Cebu Philippines 29 May-2 June 2017

reserves (99 per cent) is located around the sub-tropical Kermadec Islands, and the sub-Antarctic Auckland Islands. ${ }^{11}$

A review of the MRA was launched by the Department of Conservation in September 2000, ${ }^{12}$ which resulted in the Marine Reserves Bill $2002^{13}$ being introduced into Parliament on 7 June 2002. Subsequently, the review did not gain any traction, and the Bill was finally discharged on 26 February 2013 prior to its second reading. ${ }^{14}$ Both the current MRA and the proposed Marine Reserves Bill 2002 have been criticised by the Environmental Defence Society (EDS) as being inadequate for achieving the objective of preserving New Zealand's unique marine areas in their natural state. Instead, EDS has proposed that a wider approach should be adopted regarding marine protected areas (MPAs) as an integral component of an oceans policy, based on marine spatial planning techniques similar to the non-statutory plan regarding the Hauraki Gulf Marine Park. ${ }^{15}$

\section{New marine protected areas legislation}

The previous Government launched a consultation process regarding a new Marine Protected Areas Act in January 2016 with the objective of introducing draft legislation into Parliament during 2017. The proposed new statute moves away from the "no take" one size fits all approach

11 Ministry for the Environment, Environment New Zealand 2007 (n 10) 334.

12 Department of Conservation, Tapui Taimoana - Reviewing the Marine Reserves Act 1971 (Department of Conservation, Wellington,2000).

13 Government Bill, 224-1.

14 Marine Reserves Bill 2002 (224-1) Local Government and Environment Committee Report, which recommended on 12 December 2012 that the Bill not be passed. The Minister of Conservation had previously advised the Committee on 28 February 2012 that "the Government had reassessed the usefulness of the bill" in light of the Marine and Coastal Area (Takutai Moana) Act 2011 and the Exclusive Economic Zone and Continental Shelf (Environmental Effects) Bill 2011 (321-1), and that "the Government intends to introduce a new Marine Reserves Bill which would be better aligned with Government policy and EEZ legislation": Marine Reserves Bill 2002 (224-1): Local Government and Environment Committee Report, (New Zealand Parliament, Wellington, 12 December 2012) 2.

15 Kate Mulcahy, Raewyn Peart and Abbie Bull, Safeguarding Our Oceans: Strengthening marine protection in New Zealand (Environmental Defence Society, 2012) at 138-140; Sea Change - Tai Timu Tai Pari: Hauraki Gulf Marine Spatial Plan (April 2017). 
IUCN Academy of Environmental Law $15^{\text {th }}$ Colloquium University of Cebu Philippines 29 May-2 June 2017

to MPAs currently enshrined in the MRA to include marines reserves, species-specific sanctuaries, seabed reserves and recreational fishing parks. But notwithstanding the EDS critique, the focus remains on the $12 \mathrm{~nm}$ territorial sea. For example, the consultation document stated: ${ }^{16}$

\begin{abstract}
The new MPA Act will allow the creation of MPAs in New Zealand's territorial sea, which reflects the current scope of the Marine Reserves Act. The territorial seas is where the highest level of competition for access and resources currently exists, where the risks to marine biodiversity are greatest and where a large number of commercial, recreational and cultural activities take place. Because of this, we know more about the marine environment in the territorial sea than in other areas under New Zealand's jurisdiction.
\end{abstract}

The government considered that a fresh approach to MPAs was required in order to strike a balance between the competing interests in the New Zealand territorial sea to establish a representative network of MPAs, while allowing recreational, cultural and economic benefits to be managed sustainably and optimized. The consultation document identified a number of issues with the current approach in the MRA including the focus on scientific research as the raison d'etre for marine reserves, the consultation process (which does not envisage the use of collaborative processes that are now becoming a feature of New Zealand environmental law generally), ${ }^{17}$ and the failure to provide for economic growth. While the document envisaged that all 44 marine reserves would be rolled-over into the new statutory regime and that additional MPAs would also be established over time, it also proposed that MPAs should be subject to periodic review to ensure that they continue to meet the objectives underlying their designation. In addition to these reforms, the document also proposed special purpose legislation to establish the $624,000 \mathrm{sq}$ km Kermadec Ocean Sanctuary in the New Zealand exclusive economic zone (EEZ). Arguably, this move could result in the fragmentation of this area of law. The previous Government was however unable to introduce the proposed new Marine Protected Areas Act into Parliament during 2017 due to delays encountered with the special purpose legislation for the

16 Ministry for the Environment, A New Marine Protected Areas Act (n 1) 16.

17 Resource Management Act 1991, sch 1 (as amended by the Resource Legislation Amendment Act 2017). 
IUCN Academy of Environmental Law $15^{\text {th }}$ Colloquium University of Cebu Philippines 29 May-2 June 2017

Kermadec Ocean Sanctuary (noted below) and the impending campaign for the 23 September 2017 general election. Proposals for a new Marine Protected Areas Act will therefore rest with the new Labour, New Zealand First, and Green party coalition Government. However, early signs from policy announcements to date indicate that the new Government is likely to have a strong emphasis on the environment.

\section{Our marine environment}

The Environmental Reporting Act 2015 (ERA) ushered in a statutory requirement for state of the environment reporting in New Zealand across five domains, namely, marine, fresh water, climate and atmosphere, land, and air. Biodiversity is recognized as a cross-cutting issue across all environmental reporting domains. The reports are prepared jointly by the Ministry for the Environment and Statistics New Zealand. The first marine report covering data in the period to 2015 was published in October 2016. The report idetified three top issues, namely: ${ }^{18}$

- Global GHG emissions are causing ocean acidification and warming.

- Native marine birds and mammals are threatened with extinction.

- Coastal marine habitats and ecosystems are degraded.

These issues were selected due to: ${ }^{19}$

... the scale of harm, or potential harm, to natural systems - ocean warming and acidification have widespread implications for species and ecosystems across the exclusive economic zone (EEZ) and territorial sea.

The report noted that limited data was available regarding the marine environment. It found that ocean warming was the principal cause of

18 Ministry for the Environment and Statistics New Zealand, Our marine environment 2016 (n 2) 8.

19 Ministry for the Environment and Statistics New Zealand, Our marine environment 2016 (n 2) 9. 
IUCN Academy of Environmental Law $15^{\text {th }}$ Colloquium University of Cebu Philippines 29 May-2 June 2017

sea level rise and that New Zealand waters had warmed by 0.71 degrees Celsius during the period 1909-2009; that 25 per cent of marine mammal species are threatened with extinction; and that increased levels of sedimentation, heavy metals and invasive pest species posed risks for coastal ecosystems. ${ }^{20}$ In contrast with the limited focus of the consultation document regarding a new Marine Protected Areas Act, the marine environment report focused on New Zealand waters as a whole including the EEZ and extended continental shelf area. ${ }^{21}$ Finally, the impact of fishing on the marine environment was reported on as a cross-cutting issue. The report found that seabed trawling (while decreasing) continues with 72,000 trawl tows recorded in 2014, and that 17 per cent of commercial fish stocks were recorded as "overfished" in 2015 notwithstanding the sophisticated quota management system in place under the Fisheries Act $1996 .^{22}$

\section{Marine economy}

Separately, Statistics New Zealand also reported on the marine economy in October 2016, and observed that: ${ }^{23}$

Our marine environment is intricately linked to our society and economy. Almost all our imports and exports, both by value and volume, pass through the marine environment; most of our oil and gas reserves are located offshore; and our fishing industry is significant. Yet there is limited understanding of how much these and other activities together contribute to New Zealand's economy.

Overall, the report found that the marine economy contributed some NZD \$4 billion or 1.9 per cent of GDP to the national economy, with the oil and gas industries, shipping, and fisheries and aquaculture being predominant. ${ }^{24}$ Other sectors contributing to the marine economy include marine construction, marine tourism and recreation,

20 Ministry for the Environment and Statistics New Zealand, Our marine environment 2016 (n 2) 10, 11, and 13.

21 Ministry for the Environment and Statistics New Zealand, Our marine environment 2016 (n 2) 17.

22 Ministry for the Environment and Statistics New Zealand, Our marine environment 2016 (n 2) 55.

23 Statistics New Zealand, New Zealand's marine economy: 2007-13 (n 3 ) 5.

24 Statistics New Zealand, New Zealand's marine economy: 2007-13 (n 3 ) 6. 
IUCN Academy of Environmental Law $15^{\text {th }}$ Colloquium University of Cebu Philippines 29 May-2 June 2017

and research and education which together represent $6 \%$ of the marine economy. Internationally, the significance of the marine economy as a proportion of national economies varies between 1.2 per cent and 4.9 per cent of GDP across OECD countries, with the marine economy making the most significant contribution in the United Kingdom. ${ }^{25}$ Again, the report focused on New Zealand waters including the EEZ.

On a broader scale, Alexander Gillespie noted the economic "spillover benefits" of marine protected areas through "no-catch" restrictions that result in both the recovery of endangered species and biomass within MPAs and significant increases in commercial fish stocks in surrounding waters. ${ }^{26}$ Similarly, Donald Rothwell and Tim Stephens identified both the delicate natural characteristics and economic potential of MPAs when they observed that: ${ }^{27}$

MPAs, particularly of biologically rich zones such as coral reefs, are recognised as being able to deliver a collection of ecological, social and economic benefits, and can also ensure that marine ecosystems are made more resilient to pressures such as climate change.

Robin Kundis Craig also noted the "spillover effects" of MPAs and the scientific evidence regarding "improved fisheries" in surrounding waters derived from case studies in Florida and St Lucia. ${ }^{28}$ Overall, she observed that MPA's should be considered as part of the wider context of "place-based management tools" and noted the findings of the IUCN World Commission on Protected Areas that: ${ }^{29}$

25 Statistics New Zealand, New Zealand's marine economy: 2007-13 (n 3) Table 1, 12.

26 Alexander Gillespie, Protected Areas and International Environmental Law (Martinus Nijhoff Publishers, Leiden, 2007), 70-71; Alexander Gillespie International Environmental Law, Policy, and Ethics (2 ${ }^{\text {nd }}$ edn Oxford University Press, Oxford, 2014), 30.

27 Donald R Rothwell and Tim Stephens, The International Law of the Sea (Hart Publishing, Oxford, 2010), 466.

28 Robin Kundis Craig, Comparative Ocean Governance: Place-Based Protections in an Era of Climate Change (Edward Elgar Publishing, Cheltenham, 2012), 101-102.

29 Craig, Comparative Ocean Governance: Place-Based Protections in an Era of Climate Change (n 28) 102; IUCN World Commission on Protected Areas Establishing Marine Protected Area Networks - Making it Happen (2008). 
IUCN Academy of Environmental Law $15^{\text {th }}$ Colloquium University of Cebu Philippines 29 May-2 June 2017

If designed correctly and managed well, MPAs have an important role to play in protection of ecosystems and, in some cases, enhancing or restoring the productive potential of coastal and marine fisheries. However, it is recognized that MPAs are not the only solution for coastal and marine problems. For example, when MPAs are used in conjunction with other management tools, such as integrated coastal management ... marine spatial planning and broad area based fisheries management, they offer the cornerstone of the strategy for marine conservation. The benefits that MPAs can deliver are also related to the effectiveness of the management outside of the MPAs ...

However, Craig found that MPAs may not be fully effective where limited "scientific knowledge" affects initial decisions regarding the "placement and design" of the reserve, where the "socio-ecological dimension" of how the MPA will be governed is not taken into account via "public participation", and where the knowledge gap results in "unintended consequences". ${ }^{30}$ For example, where predatory species recover at faster rates than other species.

\section{Biodiversity action plan}

New Zealand is a party to the Convention on Biological Diversity 1992 (CBD). It has adopted a balanced approach to conservation and development and prepared the non-statutory New Zealand Biodiversity Strategy in 2000 to assist with implementation of the CBD. ${ }^{31}$ The general theme of the strategy is to halt the decline of indigenous biodiversity. More recently, the non-statutory Biodiversity Action Plan 2016-2020 has been prepared. ${ }^{32}$ Generally, the action plan includes no specific targets regarding the marine environment. The plan focuses on environmental reporting since 2015. It encourgaes a move towards an ecosystems approach to fisheries management by 2020, completion of the non-statutory approach to marine spatial planning for Hauraki Gulf. It also encourages the incorporation of indigenous knowledge and

30 Craig, Comparative Ocean Governance: Place-Based Protections in an Era of Climate Change (n 28) 105.

31 Department of Conservation, The New Zealand Biodiversity Strategy (Department of Conservation, Wellington, 2000).

32 Department of Conservation, New Zealand Biodiversity Action Plan (n 4). 
IUCN Academy of Environmental Law $15^{\text {th }}$ Colloquium University of Cebu Philippines 29 May-2 June 2017

values (again by 2020) in order to "utilise our marine resources within environmental limits". ${ }^{33}$

\section{Kermadec Ocean Sanctuary}

The Kermadec Ocean Sanctuary Bill ${ }^{34}$ is designed to establish a new marine protected area within the New Zealand EEZ around the Kermadec Islands to preserve the area in its natural state. The Bill was introduced into Parliament on 8 March 2016 and was reported back from the Local Government and Environment Committee on 22 July 2016. Subsequent progress of the Bill has been delayed by litigation against the Crown by Te Ohu Kaimoana (representing Maori fishing interests) who claim that the Minister for the Environment failed to consult with Maori regarding the potential effect of the proposed sanctuary on customary fishing rights before introducing the Bill into Parliament. $^{35}$

The Bill (if enacted) will establish the $624,000 \mathrm{sq} \mathrm{km}$ Kermadec Ocean Sanctuary. ${ }^{36}$ The sanctuary is defined as including all waters, seabed, and subsoil within the New Zealand EEZ surrounding the Kermadec Islands, excluding marine reserves in the territorial sea around the islands. ${ }^{37}$ Within the sanctuary activities will generally be prohibited, including, fishing, mining, disturbance or removal of living or non-living material from the seabed or subsoil, dumping waste, causing vibrations (except from ship propulsion), and seismic surveying. ${ }^{38}$ The prohibition will not apply to any activities expressly authorized by a permit granted by the Environmental Protection Authority (EPA), or carried out in accordance with any regulations or specific statutory

\footnotetext{
33 Department of Conservation, New Zealand Biodiversity Action Plan (n 4) 45.

34 Government Bill, 120-2.

35 Radio New Zealand, "Government to delay Kermadec Ocean Sanctuary Bill" (14 September 2016).

$36 \mathrm{KOSB}, \mathrm{s} 8$.

37 KOSB, sch 2.

38 KOSB, ss 9-10.
} 
IUCN Academy of Environmental Law $15^{\text {th }}$ Colloquium University of Cebu Philippines 29 May-2 June 2017

exemptions. ${ }^{39}$ Provision is made for the interface between the legal regime relating to the sanctuary and permissions granted under other statutes pertaining to the New Zealand EEZ, and compliance with all relevant statutes and regulations is required. ${ }^{40}$ Consistent with permitting generally within the New Zealand EEZ, provision is also made for authorizations to be granted by the EPA for marine scientific research (including requirements for impact assessment of applications under ss 16 and 17). ${ }^{41}$ In particular, marine scientific research is defined as research to ensure the preservation of the sanctuary in its natural state, that is carried out in a way that will avoid significant adverse effects on the environment. ${ }^{42}$ Consistent with the management of the terrestrial Crown conservation estate, the Bill also establishes a conservation board to oversee the preparation of conservation management strategies for the sanctuary, and the implementation of relevant statutes, regulations, policies and strategies within the sanctuary. ${ }^{43}$ Uniquely, the Bill also provides for the review of the operation of the statute. ${ }^{44}$ This will entail the appointment of a review panel jointly by the Minister of Conservation and the Minister for the Environment, and the preparation of a report and recommendations by the panel regarding the extent to which the purpose of the statute (preserving the sanctuary in its natural state) has been achieved. The review must be commenced within the period of 25 years from the statute coming into force as law. Depending on the parliamentary timetable for enacting the Bill, the Local Government and Environment Committee envisaged that this could occur before 1 November 2041.

39 For example, actions to eradicate invasive pest species in accordance with the Biosecurity Act 1993; activities regulated under the EEZCS Act 2012 regarding the construction and removal of submarine pipelines and cables, emergency dumping, or any other activity expressly permitted under the EEZCS Act 2012; and activities regulated under the Maritime Transport Act1994 in relation to marine pollution caused by hazardous ships and oil spills.

40

KOSB, ss 11-12.

41 KOSB, ss 12A-22D.

$42 \mathrm{KOSB}, \mathrm{S} 12 \mathrm{~A}$.

43 KOSB, ss 23-26.

44 KOSB, ss 27A and 27B. 
IUCN Academy of Environmental Law $15^{\text {th }}$ Colloquium University of Cebu Philippines 29 May-2 June 2017

The Bill also includes proposed amendments to a range of other statutes that apply across the New Zealand EEZ. They include amendments to the Biosecurity Act 1993 to provide for the eradication of invasive pest species within the sanctuary; ${ }^{45}$ amendments to the Conservation Act 1987 to provide for general policies and conservation management strategies to be made to guide discretionary decisionmaking regarding the sanctuary ${ }^{46}$ amendments to the Crown Minerals Act 1991 to prohibit the grant of permits regarding the exploration or exploitation of Crown minerals (e.g. oil and gas) within the sanctuary; ${ }^{47}$ amendments to the Exclusive Economic Zone and Continental Shelf (Environmental Effects) Act 2012 (EEZCS Act 2012) to provide for additional restrictions on activities within the sanctuary and to provide for strict liability criminal offences; ${ }^{48}$ and amendments to the Fisheries Act 1986 to prohibit fishing within parts of the sanctuary and consequential amendments to the quota management scheme. $^{49}$

The jurisdictional basis for the Bill was carefully set out in the commentary on the Bill as reported back from the Local Government and Environment Committee. The report stated that: ${ }^{50}$

The New Zealand Government has jurisdiction under Article 56 of the United Nations Convention on the Law of the Sea (UNCLOS) to, among other things, protect and preserve the marine environment within New Zealand's exclusive economic zone. Article 192 also imposes a general obligation on States to protect and preserve the marine environment.

Under the Fisheries Act and Articles 61 and 62 of UNCLOS, no other State could allege a right to access the fisheries resources within the proposed sanctuary without New Zealand having expressed a surplus

\footnotetext{
$45 \mathrm{KOSB}$, sS 28-29.

46 KOSB, SS 30-33.

$47 \mathrm{KOSB}$, sS $33 \mathrm{~A}$ and $33 \mathrm{~B}$.

48 KOSB, ss 34-45.

49 KOSB, sS 46-49.

50 Kermadec Ocean Sanctuary Bill As reported back from the Local Government and Environment Committee (New Zealand Parliament, Wellington, 22 July 2016) 2.
} 
IUCN Academy of Environmental Law $15^{\text {th }}$ Colloquium University of Cebu Philippines 29 May-2 June 2017

allowable catch within the area. Permission would also need to be granted by the responsible Minister.

The bill would permit the passage of ships and planes, marine scientific research, and some other activities such as the laying of submarine cables and pipelines.

Research that would otherwise breach one of the sanctuary's prohibitions would need to be approved by the Environmental Protection Authority (EPA).

Notwithstanding the clarity of this position, the previous Government was reluctant to extend the marine reserves regime generally across the New Zealand EEZ. For example, the outgoing Minister for the Environment (Hon Dr Nick Smith) stated in the media that the EEZ was "legally more complex", that New Zealand's jurisdictional control was limited, and that providing for "marine reserves in the EEZ would interfere with New Zealand's obligations to allow undersea cables to be constructed within this area". ${ }^{51}$ However, the Minister saw no reason why other "no-take zones in the deep seas" should not be established in the future under the aegis of special "one-off" statutes. ${ }^{52}$

Both the Labour Party and the Green Party recorded separate minority views in the report back from the Local Government and Environment Committee on the Bill. ${ }^{53}$ While both parties expressed concern regarding the failure of the Crown to consult with Maori on the potential impact of the Bill on customary fishing rights, the Green Party also sought "a clear process for establishing marine protected areas in the EEZ which ensures [indigenous] Treaty rights are respected and implemented, and that the Crown consults properly". ${ }^{54}$

Following the 23 September 2017 general election the Labour, New Zealand First, and Green party coalition government was sworn in on 26 October 2017. In particular, the coalition agreement (as reported

51 New Zealand Herald, "Nick Smith rejects extended marine protection laws" (13 January 2016)

52 New Zealand Herald, "Nick Smith rejects extended marine protection laws" (13 January 2016).

53 Kermadec Ocean Sanctuary Bill As reported back from the Local Government and Environment Committee (n 50) 8-9 and 10-11.

${ }^{54}$ Kermadec Ocean Sanctuary Bill As reported back from the Local Government and Environment Committee (n 50) 10. 
IUCN Academy of Environmental Law $15^{\text {th }}$ Colloquium University of Cebu Philippines 29 May-2 June 2017

by the media) indicates that the parties have agreed to "work towards a Kermadec Ocean Sanctuary". ${ }^{55}$ Accordingly, the position of the new Government regarding both establishing the sanctuary and providing for marine protected areas more generally throughout the New Zealand EEZ remains a work in progress.

As noted above, progress of the Bill has been delayed by litigation against the Crown by $\mathrm{Te}$ Ohu Kaimoana. Most recently, the proceedings have been stayed by the High Court on the ground that they impeach or question matters currently before Parliament. ${ }^{56}$ While the new Government clearly intends to proceed cautiously, it is for note that the claim regarding the potential effect of the proposed sanctuary on customary fishing rights appears to be questionable. Maori hold significant quota entitlements under the Fisheries Act 1986 that were awarded to resolve historic grievances against the Crown under the Treaty of Waitangi Act 1975, however, Ben France-Hudson has observed that the legal nature of these rights will be critical to the success of this aspect of the claim. He noted that: ${ }^{57}$

\begin{abstract}
... the property right is in a share of the catch, which can go up or down or even be non-existent in any particular period. It is not an immutable property right in the fish, or even in the ability to definitively catch fish in any given year. It is dependent on the level that the total catch is set at, which in turn is determined by a range of factors prescribed in law including environmental, cultural and recreational considerations. Thus, while quotas are a type of private property, the property right is in the quota shares, which are fluctuating and contingent. The possibility that quotas may not entitle a fisher to any fish is structured into the bedrock of the property right.
\end{abstract}

This led France-Hudson to conclude that while the claim regarding the potential effect of the proposed sanctuary on customary fishing rights has little merit at law, "the claim that the Crown breached its duty of

55 New Zealand Herald, "Revealed: Labour-NZ First coalition agreement" (24 October 2017).

56 Parliamentary Privilege Act 2014, s 11; Ngati Mutunga O WhareKauri Asset Holding Company Ltd v Attorney-General [2017] NZHC 2482.

57 Ben France-Hudson, "The Kermadec/Rangitahua Ocean Sanctuary: Expropriation-free but a breach of good faith" [2016] RM Theory \& Practice $55,66$. 
IUCN Academy of Environmental Law $15^{\text {th }}$ Colloquium University of Cebu Philippines 29 May-2 June 2017

good faith to Maori is both strong and depressingly familiar". ${ }^{58}$ However, the dynamic of recent Treaty settlements regarding indigenous grievances against the Crown has created new mechanisms for environmental regulation, such as co-governance regarding the Waikato River and guardianship and legal personality for the Whanganui River, 59 which provide hope for an "innovative" resolution in this case. ${ }^{60}$

Overall, there are strong pointers in the New Zealand policy debate which suggest that a wider conception of MPAs will ultimately be adopted. These pointers include the linkage between provision for MPAs and the development of a coherent oceans policy regarding the New Zealand EEZ and continental shelf area, the statistical approach to state of the environment reporting which views the marine environment holistically and economic analysis that clearly identifies the intrinsic links between economic activity and marine protection, and the dynamic development of indigenous governance concepts about environmental guardianship. While not expressly designed for the purpose, the KOSB provides a blueprint for enabling MPAs to be established within the New Zealand EEZ consistent with other oceans related statutes currently in force and New Zealand's rights and obligations under the LOSC.

\section{TRANS-NATIONAL PERSPECTIVES}

This section analyses the development of marine international law from soft law declaraions to multi-lateral treaty based provisions that provide jurisdiction and legitimacy for establishing MPAs within the EEZ and areas beyond national jurisdiction. It demonstrates creativity through the adoption of a variety of regional initiatives. While

58 France-Hudson, "The Kermadec/Rangitahua Ocean Sanctuary: Expropriation-free but a breach of good faith" (n 56) 55.

59 Waikato-Tainui Raupatu Claims (Waikato River) Settlement Act 2010; Te Awa Tupua (Whanganui River Claims Settlement) Act 2017.

60 France-Hudson, "The Kermadec/Rangitahua Ocean Sanctuary: Expropriation-free but a breach of good faith" ( $n$ 56) 55, 80. 
IUCN Academy of Environmental Law $15^{\text {th }}$ Colloquium University of Cebu Philippines 29 May-2 June 2017

comparative analysis highlights the methods used for transposing international obligations into domestic law.

\section{Vertical comparison with the international legal order}

The underlying thesis of this part is that notwithstaning a clear view that there are no legal impediments under the current international treaty regime to establishing MPAs within the EEZ and areas beyond national jurisdiction, residual uncertainty has provided the catalyst for the negotiation of a new implementing agreement under the LOSC.

\section{a) Marine protected areas within the EEZ}

Yoshifumi Tanaka noted that the focus on the conservation of biodiversity is a relatively recent concern of international law. ${ }^{61}$ For example, principle 2 of the Stockholm Declaration 1972 provided an important foundation for developing protected areas generally that is reflected in subsequent documents. It stated that:

The natural resources of the earth including the air, water, land, flora and fauna and especially representative samples of natural ecosystems must be safeguarded for the benefit of the present and future generations through careful planning or management, as possible.

Craig also drew attention to the impact of the UN Conference on Environment and Development 1992 on the development of MPAs. For example, Agenda 21 emphasized that: ${ }^{62}$

... states should identify marine ecosystems exhibiting high levels of biodiversity and productivity and other critical habitat areas and should provide necessary limitations on use in these areas, through, inter alia, designation of protected areas.

Similarly, the Johannesburg World Summit on Sustainable Development 2002 encouraged states to designate: ${ }^{63}$

61 Yoshifumi Tanaka, The International Law of the Sea ( $2^{\text {nd }}$ edn Cambridge University Press, Cambridge, 2015) 336.

62 Agenda 21, paragraph 17.85.

63 Johannesburg World Summit on Sustainable Development, paragraph 32(c). 
IUCN Academy of Environmental Law $15^{\text {th }}$ Colloquium University of Cebu Philippines 29 May-2 June 2017

... marine protected areas consistent with international law and based on scientific information, including representative networks by 2012 and time/area closures for the protection of nursery grounds and periods.

Likewise, the conference of parties for the Convention on Biological Diversity 1992 (CBD) noted the decline in marine biodiversity as a result of "acute human pressure", urged member states to establish MPAs as a matter of "high priority", and agreed that: ${ }^{64}$

... marine and coastal protection areas are one of the essential tools and approaches in the conservation and sustainable use of marine and coastal biodiversity.

While, Tanaka found that there appears to be no "universal" definition of marine protected areas he cited with approval the definition used in relation to the Convention on the Protection of the Marine Environment of the North-East Atlantic 1992 (OSPAR) that defines an MPA as: ${ }^{65}$

\begin{abstract}
... an area within or adjacent to the marine environment, together with its overlying waters and associated flora and fauna, and historical and cultural features, which has been reserved by legislation or other effective means, including custom, with the effect that its marine and/or coastal biodiversity enjoys a higher level of protection than its surroundings.
\end{abstract}

This led him to note the gradual uptake of MPA approaches in modern international treaties. For example, the Ramsar Convention 1971 regarding wetlands of international importance has been used to protect the shell banks and mangroves at Miranda in the Firth of Thames, New Zealand; and the World Heritage Convention 1972 (WHC) has been used to designate the $127,900 \mathrm{sq} \mathrm{km}$ Great Barrier Reef straddling the Australian territorial sea and EEZ. ${ }^{66}$ Overall, Tanaka found that these approaches were "piecemeal" and that a more comprehensive international response was required to develop customary international law and influence state practice. ${ }^{67}$

64 CBD Conference of the Parties (February 2004) COP VII/5, paragraphs 11, $12,16,18$, and $20-22$.

65 OSPAR Recommendation 2003/3 adopted by OSPAR 2003 (OSPAR 03/17/1, Annex 9), amended by OSPAR Recommendation 2010/2 (OSPAR 10/23/1, Annex 7) para 1.1.

66 Tanaka, The International Law of the Sea (n 60) 346-347.

67 Tanaka, The International Law of the Sea (n 60) 338. 
IUCN Academy of Environmental Law $15^{\text {th }}$ Colloquium University of Cebu Philippines 29 May-2 June 2017

However, Tanaka took comfort from the general obligations in art 194(5) of the LOSC that provide a more global foundation for conserving marine biodiversity. It states that:

The measures taken in accordance with this Part XII shall include those necessary to protect and preserve rare or fragile ecosystems as well as the habitat of depleted, threatened or endangered species and other forms of marine life.

While state jursidiction under the LOSC arguably focuses on the territorial sea, it also imposes a duty on states to protect the marine environment (art 193) and control marine pollution (art 234) in any declared EEZ. Similarly, in relation to the high seas there are no express provisions to give states a handle for conserving marine biodiversity in areas beyond national jurisdiction, but there is a general duty for states to cooperate and use the high seas for peaceful purposes (art 141), and the International Seabed Authority (ISA) is given general responsibility to protect the marine environment. ${ }^{68}$

Tanaka also took comfort from the principles in the CBD regarding sustainable use and fair and equitable benefit sharing (arts 1 and 15), and found that they balances sovereign rights against the obligation not to cause environmental damage. Overall, from the perspective of conserving marine biodiversity the $\mathrm{CBD}$ focuses on in-situ conservation through regulation, designating protected areas, ecosystem rehabilitation, risk management, eradicating alien species, and managing activities. Beyond that, the CBD also includes procedural rules to minimize the adverse effects of activities via requirements for the assessment of environmental effects, and imposes a general duty on states to consult with other states and notify them about any environmental damage (art 14).

While Philippe Sands took the more robust view that "coastal states are entitled to establish an MPA" in the EEZ, he noted that the ability to exercise this power was subject to the general provisions in the

68 Tanaka, The International Law of the Sea (n 60) 339-340. 
IUCN Academy of Environmental Law $15^{\text {th }}$ Colloquium University of Cebu Philippines 29 May-2 June 2017

LOSC. $^{69}$ He also drew attention to the Chagos Marine Protected Area Arbitration where Mauritius challenged the legality of the declaration of the MPA by the United Kingdom based on a dispute regarding the sovereignty of the Chagos Islands, and whether in the context of this case the United Kingdom was a coastal state. Although the Permanent Court of Arbitration upheld the challenge by Mauritius, it was careful to state that: ${ }^{70}$

In concluding that the declaration of the MPA was not in accordance with the provisions of the Convention, the Tribunal has taken no view on the substantive quality or nature of the MPA or on the importance of environmental protection. The Tribunal's concern has been with the manner in which the MPA was established, rather than its substance. It is now open to the Parties to enter into the negotiations that the Tribunal would have expected prior to the proclamation of the MPA, with a view to achieving a mutually satisfactory arrangement for protecting the marine environment ...

As a result, the more robust opinion expressed by Sands was vindicated.

\section{b) Areas beyond national jurisdiction}

Tanaka found that there was legal uncertainty regarding the basis for designating MPAs in areas beyond national jurisdiction. He distinguished on the one hand between MPAs in the high seas in the "broad sense", namely, in areas where states could declare an EEZ but have elected not to do so. ${ }^{71}$ For example, in the Mediterranean where the France-Italy-Monaco MPA has been designated to protect marine mammals in their quasi-EEZ area that includes the power under the agreement between these states to enforce the restictions pertaining to the MPA against ships flying third party state flags. ${ }^{72}$ On the other hand, Tanaka noted the ability to designate MPAs in areas beyond national jurisdiction in the "strict sense" under the aegis of an

69 Philippe Sands and others, Principles of International Environmental Law ( $3^{\text {rd }}$ edn, Cambridge University Press, Cambridge, 2012) 444.

70 In the matter of the Chagos Marine Protected Area Arbitration (Mauritius $v$ United Kingdom) Permanent Court of Arbitration (2015) paragraphs 544547.

71 Tanaka, The International Law of the Sea (n 60) 351-352.

72 Tanaka, The International Law of the Sea (n 60) 351. 
IUCN Academy of Environmental Law $15^{\text {th }}$ Colloquium University of Cebu Philippines 29 May-2 June 2017

international agreement, such as, the CCAMLR 60 degrees south MPA where fishing and dumping are prohibited. ${ }^{73}$

He therefore found that designating MPAs in areas beyond national jurisdiction "is not free from controversy". ${ }^{74}$ In particular, he noted the narrow legal basis for MPAs in the high seas founded on the duties to protect fragile ecosystems under art 194 of the LOSC, and requiring state cooperation under art 118 of the LOSC. He also noted that third party navigation rights will generally prevail, that there are currently no objective criteria for establishing MPAs, that designating MPAs could conflict with continental shelf delimitation, the possible need for agreement with the ISA given its general oversight of the marine environment under the LOSC, and that fishing is generally unregulated and tends to fall outside regional agreements (e.g. OSPAR). Generally, he observed the critical need for an integrated approach between designating an MPA and implementing marine pollution regulations in the area, and the need to control the adverse effects of climate change on marine biodiversity. ${ }^{75}$

Sands, however, again took a more robust view of the LOSC provisions and stated that: ${ }^{76}$

\footnotetext{
Essentially, there is no legal impediment on establishing MPAs in the high seas. The real challenge lies in reconciling the interests of states supporting the establishment of a protected area with those of states that prefer to make other legal uses of that area.

This led him to observe that states have begun to grapple with the challenge of reaching such compromises under the umbrella of regional
} initiatives.

\section{c) Regional initiatives}

Churchill and Lowe insightfully observed that: ${ }^{77}$

\footnotetext{
73 Tanaka, The International Law of the Sea (n 60) 352-353.

74 Tanaka, The International Law of the Sea (n 60) 355.

75 Tanaka, The International Law of the Sea (n 60) 355-56.

76 Sands, Principles of International Environmental Law (n 68) 445.
} 
IUCN Academy of Environmental Law $15^{\text {th }}$ Colloquium University of Cebu Philippines 29 May-2 June 2017

The principle of sustainable development is obviously primarily concerned with natural resources, but both it and the maintenance of biological diversity require a marine environment free of significant pollution for their effective realisation.

They also mapped the conceptual development of MPAs. They noted the shift from a narrow focus on preventing marine pollution to a wider "realisation of the need to take more positive measures to conserve marine life and habitats" reflected in art 194(5) of the LOSC. ${ }^{78}$ They observed that these principles had been implemented via the United Nations Environment Programme (UNEP) Regional Seas programme, set up following the UN Conference on the Human Environment (Stockholm) 1972. ${ }^{79}$ For example, the initial Protocol on Mediterranean Specially Protected Areas 1982 imposed an obligation on the parties to identify sites of "biological and ecological value" and put in place measures designed to protect them. ${ }^{80}$ Subsequently, the replacement Protocol concerning Specially Protected Areas and Biological Diversity in the Mediterranean 1995 placed greater emphasis on establishing specially protected areas in relation to biodiversity conservation, protecting the habitat of endangered species, and for scientific and cultural reasons. They noted the growth of the UNEP programme with similar protocols being adopted for East Africa 1985, the South-East Pacific 1989, and the Carribean 1990; while Rothwell and Stephens noted (in particular) the treaty-based foundation of the programme and observed that: ${ }^{81}$

The RSP operates through regional action plans, addressing matters such as environmental assessment, environmental management, environmental legislation, institutional arrangements and financial arrangements. In most cases these action plans are given a binding legal basis through regional conventions and protocols.

Kenchington and Warner also recorded the success of regional initiatives, such as the Coral Triangle Initiative (CTI) endorsed by

77 RR Churchill and AV Lowe, The Law of the Sea ( $3^{\text {rd }}$ edn Manchester University Press, Manchester, 1999) 336-337.

78 Churchill and Lowe, The Law of the Sea (n 76) 392.

79 Churchill and Lowe, The Law of the Sea (n 76) 393; Rothwell and Stephens, The International Law of the Sea (n 27) 482.

80 Churchill and Lowe, The Law of the Sea (n 76) 393.

81 Rothwell and Stephens, The International Law of the Sea (n 27) 482. 
IUCN Academy of Environmental Law $15^{\text {th }}$ Colloquium University of Cebu Philippines 29 May-2 June 2017

Leaders of the Asia Pacific Economic Cooperation (APEC) in 2007, by committing to a range of measures including "the implementation of an ecosystem approach to managing fisheries and other marine resources", "the establishment of marine protected areas" to mitigate the adverse effects of climate on the marine environment, and "the establishment of a comprehensive CTI Action Plan". 82 The CTI is a "non-treaty based maritime cooperation" between six States: Indonesia, Malaysia, Philippines, Papua New Guinea, Solomon Islands, and Timor L"Este; focused on their combined (5.7 sq km) exclusive economic zones and the significant biodiversity interest in these marine waters. ${ }^{83}$ For example, they noted that: ${ }^{84}$

The Coral Triangle is regarded by scientists as one of the richest repositories of marine biodiversity on earth. It contains 76 per cent of all known coral species, 37 per cent of coral reef fish, and 33 per cent of the world's coral reefs. Further, it contains a wealth of mangrove forests and the spawning and juvenile growth areas for the world's largest tuna fishery ...

The success of the CTI relies on the way in which the member States have cooperated to manage their marine jurisdictions trans-nationally based on existing international law treaties, including, the CBD, the LOSC and the United Nations Framework Convention on Climate Change.

Beyond that, Churchill and Lowe noted the influence of CBD requirements for parties to establish protected areas, and the development of Particularly Sensitive Sea Areas (PSSA) by the International Maritime Organisation (IMO) to protect ecologically and scientifically important areas "which may be vulnerable to damage by

82 Richard Kenchington and Robin Warner, "Uncertain seas ahead: legal and policy approaches to conserving marine biodiversity in the face of climate change" in Robin Warner and Clive Schofield (eds) Climate Change and the Oceans: Gauging the Legal and Policy Currents in the Asis Pacific and Beyond (Edward Elgar Publishing, Cheltenham, 2012) 66.

83 Rothwell and Stephens, The International Law of the Sea (n 27) 485.

84 Kenchington and Warner, "Uncertain seas ahead: legal and policy approaches to conserving marine biodiversity in the face of climate change" ( $\mathrm{n}$ 81) 66; Rothwell and Stephens, The International Law of the Sea ( $\mathrm{n} 27$ ) 485. 
IUCN Academy of Environmental Law $15^{\text {th }}$ Colloquium University of Cebu Philippines 29 May-2 June 2017

maritime activities". ${ }^{85}$ In particular, PSSAs may be subject to a range of measures including: ${ }^{86}$

... designation as a special areas under MARPOL, the adoption of routing measures including designation as an area to be avoided, compulsory pilotage, the adoption of a vessel traffic management system, special construction requirements and speed restrictions ...

Additionally, where existing international rules are considered to be "inadequate" coastal states may (after consultation with the IMO) promulgate domestic laws to prevent marine pollution from vessels and introduce navigation standards in relation to MPAs under art 211(6) of the LOSC. ${ }^{87}$

The IMO has been particularly successful in establishing PSSAs to safeguard against adverse effects from shipping on the marine environment by imposing stricter controls on marine traffic. ${ }^{88}$ Other treaty systems also afford protection indirectly, for example, marine sites of special scientific interest established under the Antarctic Treaty will also have a wider benefit for the marine environment within or surrounding such sites. ${ }^{89}$ Encouraged by the IUCN, the UN has maintained an inventory of protected areas from 1958 onwards. While globally approximately 19 million $\mathrm{km} 2$ is protected, MPAs comprise less than 10 per cent of all protected areas. ${ }^{90}$

From a New Zealand perspective, Sands also noted the importance of whale sanctuaries established by the International Whaling Commission (IWC) as part of the various regional initiatives for protecting marine biodiversity. ${ }^{91}$ New Zealand was a founding member of the IWC and has been a "strong supporter" of both the moratorium

85 Churchill and Lowe, The Law of the Sea (n 76) 394.

${ }^{86}$ Churchill and Lowe, The Law of the Sea ( $n$ 76) 394.

87 Churchill and Lowe, The Law of the Sea ( $n$ 76) 395.

88 Gillespie, Protected Areas and International Environmental Law (n 26) 16$18,27$.

89 Gillespie, Protected Areas and International Environmental Law (n 26) 48.

90 Gillespie, Protected Areas and International Environmental Law (n 26) 111.

91 Sands, Principles of International Environmental Law (n 68) 446. 
IUCN Academy of Environmental Law $15^{\text {th }}$ Colloquium University of Cebu Philippines 29 May-2 June 2017

on commercial whaling and the establishment of the 50 million sq $\mathrm{km}$ Southern Ocean Sanctuary, and intervened in Whaling in the Antarctic successfully challenging the objectivity, reasonableness and proportionality of Japan's alleged scientific whaling programme. ${ }^{92}$

\section{d) Gaps in networks}

Gillespie also noted network "gaps" regarding MPAs both in terms of their cumulative extent and in relation to the legal competence to designate them. For example, MPAs cover "les than 3 per cent of the Earth's marine area", with a small number of MPAs in Australasia and Oceana accounting for the bulk of the total protected global marine area. ${ }^{93}$ Less than $0.14 \%$ coverage is currently found in areas beyond national jurisdiction. The competence to designate MPAs is also currently restricted to a relatively small number of international treaty regimes, such as, the CCAMLR, the IMO agreements, the Man and Biosphere program, the Ramsar Convention, and the WHC. For example, the WHC has proved to be relatively successful in designating MPAs around coral reefs in waters around Australia, Bangladesh, Belize, Philippines (Tubbataha Reef), Russia, and Spain; whereas, the CCAMLR has achieved more limited success in designating "only three small marine sites around the entire continent of Antarctica". ${ }^{94}$

Other institutional arrangements are less robust, and rely solely on powers of recommendation to persuade international actors to engage in designating MPAs. For example, the scientific committee constituted by the Agreement on the Conservation of Cetaceans of the Black Sea, Mediterranean Sea and contiguous Atlantic Area (ACCOBAMS) made under the auspices of the Convention on Migratory Species (CMS), and the International Coral Reef Institute (ICRI) have made such

92 www.mfat.govt.nz (accessed 1 November 2017); Whaling in the Antarctic (Australia v Japan: New Zealand intervening) ICJ Reports 2014, 226.

93 Alexander Gillespie, Conservation, Biodiversity and International Law (Edward Elgar Publishing, Cheltenham, 2012), 386.

94 Gillespie, Conservation, Biodiversity and International Law (n 92) 386-387. 
IUCN Academy of Environmental Law $15^{\text {th }}$ Colloquium University of Cebu Philippines 29 May-2 June 2017

recommendations to their members. In particular, the ICRI called for: ${ }^{95}$

... urgent actions to establish and effectively manage representative regional and national networks of marine protected areas that include coral reefs and related ecosystems, through the application of ecosystem-based approaches, and based on sound science, and consistent with international law.

This recommendation was made against the background of the CBD target adopted in 2010 aimed at "minimizing" adverse effects on coral reefs from ocean acidification by 2015 , the relatively small number of coral reefs within designated MPAs, and the fact that "at least 40 countries lacked any marine protected areas for conserving their coral reefs". ${ }^{96}$

\section{e) New international agreement}

Historically, the use of MPAs has grown significantly since the designation of the first MPA at the Fort Jefferson National Monument in Florida in $1935 .{ }^{97}$ Internationally, establishing MPAs in the high seas has (until recently) struggled to gain traction under art 192 of the LOSC despite attempts to move forward using the Open Ended Informal Consultative Process. Currently, approximately 6 per cent of territorial seas globally and less than 1 per cent of ocean space beyond sovereign territory have been designated as MPAs. ${ }^{98}$

Gillespie noted the slow progress made with designating MPAs, notwithstanding active encouragement from the IUCN since 1972 and more recently by $\mathrm{CBD}$ parties, and the available scientific evidence regarding the need to protect "seamounts, cold-water and sponge reefs and hydrothermal vents beyond national boundaries". ${ }^{99}$ While CBD parties adopted the IUCN World Parks Congress target for

95 ICRI (2007) Recommendation on Developing MPA Networks (Tokyo, ICRI General Meeting).

96 Gillespie, Conservation, Biodiversity and International Law (n 92) 387.

97 Gillespie, Protected Areas and International Environmental Law (n 26) 8.

98 Rothwell and Stephens, The International Law of the Sea (n 27) 466.

99 Gillespie, Conservation, Biodiversity and International Law (n 92) 189-190. 
IUCN Academy of Environmental Law $15^{\text {th }}$ Colloquium University of Cebu Philippines 29 May-2 June 2017

establishing "a representative network of marine protected areas by 2012" it remains unclear as to how this target (regardless of timeframe) will be accomplished within the current framework of international law pertaining to the high seas. ${ }^{100}$ Proposals made by New Zealand and the Netherlands for (respectively) the closure of regional seas to protect "vulnerable areas" from the adverse effects of "bottom trawling" and for the expansion of the LOSC regime to identify and designate MPAs "beyond national jurisdiction" have only recently met with any real success. ${ }^{101}$

For example, Edward Goodwin found that the LOSC provides coastal states with jurisdiction to establish MPAs in all marine areas with the sole exception of the high seas. Notwithstaning the "challenge" of establishing MPAs in the high seas, he noted that states have pursued the various regional initiatives noted above. ${ }^{102}$ However, gaps "persist" in the framework, ${ }^{103}$ and this led the UN General Assembly to resolve in 2013 that work should start on the formulation of a new international agreement. ${ }^{104}$ Negotiations progressed via the Ad Hoc Open-ended Informal Working Group in 2014, and via four meetings of the Preparatory Committee ${ }^{105}$ in 2016-2017 resulting in a final report on elements of a draft text for a new international agreement. ${ }^{106}$ Goodwin noted the initial reluctance of states to establish a new international institution to oversee the agreement, and the potential difficulty in implementing the agreement arising from the conclusion that this would rest with flag states - because coastal states did not

\footnotetext{
100 Gillespie, Conservation, Biodiversity and International Law (n 92) 189-190.

${ }^{101}$ UN, "The Future We Want" (2012) para 162; Gillespie, Conservation, Biodiversity and International Law (n 92) 190-191.

102 Edward J Goodwin, "Broad-spectrum efforts to enhance the conservation of vulnerable marine ecosystems" in Michael Bowman, Peter Davies and Edward Goodwin (eds) Research Handbook on Biodiversity and Law (Edward Elgar Publishing, Cheltenham, 2016) 159.

103 Goodwin, "Broad-spectrum efforts to enhance the conservation of vulnerable marine ecosystems" (n 101) 159.

104 UNGA Res 68/70 (2014), Preamble [197]-[201].

105 Established under UNGA Res 69/292 (2015).

${ }^{106}$ Fourth Session of the Prep Com (10-21 July 2017).
} 
IUCN Academy of Environmental Law $15^{\text {th }}$ Colloquium University of Cebu Philippines 29 May-2 June 2017

have the jurisdiction to establish MPAs in the high seas. ${ }^{107}$ While the report does not answer the questions of who should be responsible for designating MPAs in the high seas, it does not preclude the possibility that a new institutional framework may emerge including a representative body, scientific committee, and secretariat. More importantly, paragraph 4.3.1 of the report lays the foundation for MPAs to be identified "based on the best available scientific information" and provides an embryonic list of potential criteria to guide designation decisions. ${ }^{108}$ New Zealand has actively participated in these negotiations.

Glen Wright, Julien Rochette and Elisabeth Druel speculated about the content of the agreement and considered that: ${ }^{109}$

... it is helpful to think of the designation of an MPA as a process requiring a number of steps to be taken. These include: (i) the description of a suitable area according to determined scientific criteria; (ii) the proposal of an MPA; (iii) official designation by a competent authority; and (iv) the adoption of a management plan and management measures aimed at meeting the objectives of the MPA.

In relation to management of MPAs they focused on substance rather than form and noted that "management measures will be an essential part of ensuring the effectiveness of the MPA" (emphasis added). ${ }^{110}$ Beyond that, they observed that the relationship between existing regional initiatives and the new international agreement will be "critical" to the success of establishing a representative network of MPAs in areas beyond national jurisdiction. In particular, they noted an "underlying assumption" that these different legal arrangements

107 Goodwin, "Broad-spectrum efforts to enhance the conservation of vulnerable marine ecosystems" (n 101) 160.

${ }^{108}$ These include: uniqueness; rarity; special importance for life history stages of species; importance for threatened, endagered or declining species and/or habitats; vulnerability; fragility; sensitivity; biological productivity; biological diversity; representativeness; dependency; naturalness; connectivity; ecological processes; and economic and social factors.

${ }^{109}$ Glen Wright, Julien Rochette and Elisabeth Druel, "Marine protected areas in areas beyond national jurisdiction" in Rosemary Rayfuse (ed) Research Handbook on International Marine Environmental Law (Edward Elgar Publishing, Cheltenham, 2015) 287.

${ }^{110}$ Wright, Rochette and Druel, "Marine protected areas in areas beyond national jurisdiction" (n 108) 287. 
IUCN Academy of Environmental Law $15^{\text {th }}$ Colloquium University of Cebu Philippines 29 May-2 June 2017

should complement each other, and they suggested that existing MPAs designated under the auspices of regional initiatives could also be nominated for protection under the new agreement. ${ }^{111}$ Overall, Sands considered that these ongoing discussions about the new agreement could resolve some of the "challenges" identified (above) by Gillespie and other commentators. ${ }^{112}$

Overall, this part demonstrates the influence of the international legal order on domestic law through the application of the Ramsar Convention to designate MPAs extending into the territorial sea, and the application of the LOSC and regional initiatives to designate MPAs within the EEZ and areas beyond national jurisdiction (e.g. the proposed Kermadec Ocean Sanctuary and the Southern Ocean Whale Sanctuary). Beyond that, current international negotiations regarding a new implementing agreement under the LOSC are now advanced. Early indications are that a science based approach to designating MPAs, using sophisticated decision-making criteria that balance environmental and economic and social considerations is likely to emerge.

\section{Horizontal comparison between jurisdictions}

This part focuses on comparative analysis and highlights the methods used for transposing international obligations into domestic law.

For example, Rothwell and Stephens noted the impetus provided by the CBD Conference of Parties in 2008 for establishing "a representative network of marine protected areas". ${ }^{113}$ They found that MPA networks are now being established, including, the National Representative System of Marine Protected Areas (NRSMPA) in Australia, and under the Marine and Coastal Access Act 2009 (MCAA) in the United Kingdom. While Craig noted the progress being made by

${ }^{111}$ Wright, Rochette and Druel, "Marine protected areas in areas beyond national jurisdiction" (n 108) 288.

112 Sands, Principles of International Environmental Law (n 68) 447.

113 Decision IX/20, UN Doc UNEP/CBD/COP/DEC/IX/20 (2008); Rothwell and Stephens, The International Law of the Sea (n 78) 466. 
IUCN Academy of Environmental Law $15^{\text {th }}$ Colloquium University of Cebu Philippines 29 May-2 June 2017

the United States in establishing MPAs in a consistent way led by a "gap analysis" carrired out by the National Marine Protected Areas Centre. ${ }^{114}$ California was the first state brought into focus. She also noted the commitment made by Australia to expand its NRSMPA beyond 10 per cent of its EEZ in order to comply with the CBD. ${ }^{115}$

Similarly, the EDS report "Safeguarding Our Oceans" was designed as a catalyst for debate regarding the form of New Zealand's next generation marine protected areas legislation to replace the MRA, and provided a comparative analysis of statutes from selected jurisdictions. ${ }^{116}$ This analysis included two national statutes, namely, the Environmental Protection and Biodiversity Protection Act 1999 (Australia) and the MCAA (United Kingdom); and two sub-national statutes, namely, the Marine Life Protection Act 1999 (California) and the Marine Parks Act 1997 (New South Wales).

The report assessed the legislative framework, management measures, and design and implementation of these statutes. In relation to the legislative framework, EDS found that the Californian and the United Kingdom statutes provided a strong legal impetus for action, and while the policy approach under the Australian federal and state statutes had not been an obstacle to progress.

In relation to management measures, EDS found that all selected jurisdictions (except the United Kingdom) provided for a range of marine protected categories. For example, the MCAA provides only for the designation of marine protection zones (MPZs) with a focus on conserving marine flora and fauna, marine habitats, and features of geological or geomorphological interest. ${ }^{117}$

${ }^{114}$ Craig, Comparative Ocean Governance: Place-Based Protections in an Era of Climate Change (n 28) 103.

${ }^{115}$ Craig, Comparative Ocean Governance: Place-Based Protections in an Era of Climate Change (n 28) 104.

${ }^{116}$ Mulcahy, Peart and Bull, Safeguarding Our Oceans: Strengthening marine protection in New Zealand (n 15).

${ }^{117}$ Richard Burnett-Hall and Brian Jones (eds) Burnett-Hall on Environmental Law (3 $3^{\text {rd }}$ edn Sweet \& Maxwell, London, 2012) 403. 
IUCN Academy of Environmental Law $15^{\text {th }}$ Colloquium University of Cebu Philippines 29 May-2 June 2017

While in relation to the design and implementation of these statutes, EDS found that the Australian "top down" approach allowed for greater state direction, whereas the Californian and United Kingdom approaches provided for "significant" stakeholder invlovement with 50 MPZ having now been designated in United Kingdom waters including the EEZ covering $20,700 \mathrm{sq} \mathrm{km}$ or $20 \%$ of United Kingdom waters. This is significantly greater than the area protected under the MRA in New Zealand (7\% of the territorial sea only). Originally, 127 MPZ were proposed by the Joint Nature Conservation Committee covering 37,475 sq $\mathrm{km}$ of United Kingdom waters. Implementation of the MCAA is split, with the Department for Environment, Food and Rural Affairs (Defra) being responsible for designating MPZ, and the Marine Management Organisation (MMO) being responsible for marine spatial planning and enforcement. ${ }^{118}$

Overall, comparative analysis demonstrates that a variety of legal and policy approaches appear to be practicable. Context, however, will be everything and care will be required to ensure that comparative experience is a true fit before it is transplanted into another national jurisdictional setting. Beyond that, experience from Australia and the United Kingdom shows that gap analysis and scientific data collection, and stakeholder engagement are critical for establishing a representative network of MPAs.

\section{CONCLUSION}

While there are clear gaps in implementation, there is dynamic commitment from states to experiment with new legal and policy responses and real opportunities to learn from this experience about what works and why. This is demonstrated by the schizophrenic New Zealand experience from enacting the ground-breaking MRA in the 1970 s for designating MPAs within the territorial sea; through succumbing to doubts about international implementation gaps during the period 2002-2016 that made it difficult to establish MPAs within

${ }^{118}$ Burnett-Hall and Jones Burnett-Hall on Environmental Law (n 116) 399 and 404. 
IUCN Academy of Environmental Law $15^{\text {th }}$ Colloquium University of Cebu Philippines 29 May-2 June 2017

most parts of the New Zealand EEZ (apart from the Kermadec Islands); to active international engagement in establishing the Southern Ocean Whale Sanctuary, intervening in the Whaling in the Antarctic litigation, and participating in the negotiations for a new implementing agreement under the LOSC. These most recent actions provide hope for the future. Separately, the domestic experience from Australia and the United Kingdom underlines the critical importance of amassing reliable scientific data and engaging in meaningful stakeholder engagement if additional MPAs are to be designated in the future.

\section{Key words}

Biodiversity, Oceans, New Zealand, Trans-National, Environmental Law

\section{Bibliography}

Burnett-Hall R and Jones B (eds) Burnett-Hall on Environmental Law ( $3^{\text {rd }}$ edn Sweet \& Maxwell, London, 2012)

Churchill RR and Lowe AV, The Law of the Sea ( $3^{\text {rd }}$ edn Manchester University Press, Manchester, 1999)

Craig RK, Comparative Ocean Governance: Place-Based Protections in an Era of Climate Change (Edward Elgar Publishing, Cheltenham, 2012)

Department of Conservation New Zealand Biodiversity Action Plan 2016-2020 (Department of Conservation, Wellington, 2016)

France-Hudson B, "The Kermadec/Rangitahua Ocean Sanctuary: Expropriationfree but a breach of good faith" [2016] RM Theory \& Practice 55

Gillespie A, Protected Areas and International Environmental Law (Martinus Nijhoff Publishers, Leiden, 2007)

Gillespie A, Conservation, Biodiversity and International Law (Edward Elgar Publishing, Cheltenham, 2012) 
IUCN Academy of Environmental Law $15^{\text {th }}$ Colloquium University of Cebu Philippines 29 May-2 June 2017

Gillespie A, International Environmental Law, Policy, and Ethics ( $2^{\text {nd }}$ edn Oxford University Press, Oxford, 2014)

Goodwin EJ, "Broad-spectrum efforts to enhance the conservation of vulnerable marine ecosystems" in Bowman M, Davies P and Goodwin EJ (eds) Research Handbook on Biodiversity and Law (Edward Elgar Publishing, Cheltenham, 2016)

Kenchington $\mathrm{R}$ and Warner $\mathrm{R}$, "Uncertain seas ahead: legal and policy approaches to conserving marine biodiversity in the face of climate change" in Warner R and Schofield C (eds) Climate Change and the Oceans: Gauging the Legal and Policy Currents in the Asis Pacific and Beyond (Edward Elgar Publishing, Cheltenham, 2012)

Ministry for the Environment A New Marine Protected Areas Act: Consultation Document (Ministry for the Environment, Wellington, 2016)

Ministry for the Environment and Statistics New Zealand New Zealand's Environmental Reporting Series: Our marine environment 2016 (Ministry for the Environment and Statistics New Zealand, Wellington, 2016)

Mulcahy K, Peart R and Bull A, Safeguarding Our Oceans: Strengthening marine protection in New Zealand (Environmental Defence Society, Auckland, 2012)

Rothwell DR and Stephens T, The International Law of the Sea (Hart Publishing, Oxford, 2010)

Sands P and others, Principles of International Environmental Law ( $3^{\text {rd }}$ edn, Cambridge University Press, Cambridge, 2012)

Statistics New Zealand New Zealand's marine economy: 2007-13 (Statistics New Zealand, Wellington, 2016)

Tanaka Y, The International Law of the Sea ( $2^{\text {nd }}$ edn Cambridge University Press, Cambridge, 2015)

Wright G, Rochette J and Druel E, "Marine protected areas in areas beyond national jurisdiction" in Rayfuse R (ed) Research Handbook on International Marine Environmental Law (Edward Elgar Publishing, Cheltenham, 2015) 